ISSN 1412-2936

EISSN 2549-7308

\title{
ANALISIS NILAI PERUSAHAAN \\ BANK UMUM SYARIAH DI INDONESIA
}

\author{
ALFIAN HALID SOFIAN
}

Alfianhalid@yahoo.com

INSTITUT AGAMA ISLAM NEGERI (IAIN) MADURA

\begin{abstract}
Company value may reflect the assets owned by a company in the form of securities of one of them in the form of shares. The stock price traded on the stock exchange is an indicator of corporate value. Corporate value is influenced by many factors. This study aims examine the effect csr, profitability, liquidity, leverage and growth for the value of the company.

This research is a research using quantitative approach. The population in this study were all companies of Sharia Banks registered in Bank Indonesia, from the population used the total sampling method and the total population of 11 Sharia Commercial Banks became the sample. The data used is secondary data. Data analysis used is path analysis with SPSS 23

The results show that CSR can contribute to corporate value, profitability can not contribute to corporate value, liquidity can contribute to firm value, leverage can contribute to firm value, and growth can not contribute to firm value.
\end{abstract}

Keyword : CSR, profitability, liquidity, leverage, growth, firm value 
ISSN 1412-2936

EISSN 2549-7308

\section{PENDAHULUAN}

Nilai perusahaan dapat mencerminkan nilai asset atau aktiva yang dimiliki perusahaan seperti suratsurat berharga salah satunya berupa saham. Kemampuan perusahaan membayar dividen merupakan salah satu faktor yang mempengaruhi harga saham. Bagi perusahaan yang menerbitkan saham di pasar modal, harga saham yang diperjualbelikan di bursa efek merupakan indikator nilai perusahaan. Memaksimumkan nilai pasar perusahaan sama dengan memaksimumkan harga pasar saham.

Pergerakan saham bank umum syariah juga dapat menunjukkan eksistensi dari nilai perusahaan itu sendiri. Adapun nilai perusahaan Bank Umum Syariah dapat dilihat dalam tabel 1 berikut:

Tabel. 1 Nilai Perusahaan Bank Umum Syariah di Indonesia Tahun 2012-2015 (persen)

\begin{tabular}{|c|l|c|c|c|c|}
\hline \multirow{2}{*}{ No. } & \multirow{2}{*}{ Nama } & \multicolumn{4}{|c|}{ Tahun } \\
\cline { 3 - 6 } & Perusahaan & $\mathbf{2 0 1 2}$ & $\mathbf{2 0 1 3}$ & $\mathbf{2 0 1 4}$ & $\mathbf{2 0 1 5}$ \\
\hline 1. & $\begin{array}{l}\text { PT. Bank } \\
\text { Syariah } \\
\text { Mandiri }\end{array}$ & 46,27 & 40,80 & 37,34 & 49,52 \\
\hline 2. & $\begin{array}{l}\text { PT. Bank } \\
\text { Muamalat } \\
\text { Indonesia }\end{array}$ & 49,93 & 50,07 & 57,12 & 58,59 \\
\hline 3. & $\begin{array}{l}\text { PT. Bank } \\
\text { BNI Syariah }\end{array}$ & 35,20 & 37,03 & 40,76 & 44,22 \\
\hline 4. & $\begin{array}{l}\text { PT. Bank } \\
\text { BRI Syariah }\end{array}$ & 29,35 & 34,31 & 38,80 & 39,67 \\
\hline 5. & $\begin{array}{l}\text { PT. Bank } \\
\text { Mega } \\
\text { Syariah }\end{array}$ & 20,73 & 22,76 & 24,89 & 30,43 \\
\hline 6. & $\begin{array}{l}\text { PT. Bank } \\
\text { Jabar } \\
\text { Banten }\end{array}$ & 26,74 & 29,77 & 31,43 & 33,79 \\
\hline
\end{tabular}

\begin{tabular}{|c|l|c|c|c|c|}
\hline & Syariah & & & & \\
\hline 7. & $\begin{array}{l}\text { PT. Bank } \\
\text { Panin } \\
\text { Syariah }\end{array}$ & 29,93 & 32,90 & 23,53 & 20,91 \\
\hline 8. & $\begin{array}{l}\text { PT. Bank } \\
\text { Bukopin } \\
\text { Syariah }\end{array}$ & 31,74 & 33,47 & 34,26 & 32,87 \\
\hline 9. & $\begin{array}{l}\text { PT. Bank } \\
\text { Victoria } \\
\text { Syariah }\end{array}$ & 25,28 & 26,76 & 27,85 & 29,34 \\
\hline 10. & $\begin{array}{l}\text { PT. BCA } \\
\text { Syariah }\end{array}$ & 24,72 & 29,78 & 31,75 & 34,87 \\
\hline 11. & $\begin{array}{l}\text { PT. } \\
\text { Maybank } \\
\text { Indonesia } \\
\text { Syariah }\end{array}$ & 27,38 & 29,83 & 35,47 & 34,54 \\
\hline
\end{tabular}

Perusahaan yang memiliki total aset dengan jumlah besar akan lebih banyak mendapat perhatian investor, kreditor maupun para pemakai informasi keuangan lainnya, serta pihak manajemen akan lebih leluasa dalam menggunakan aset yang ada untuk meningkatkan nilai perusahaan. Kondisi perekonomian yang semakin tidak menentu atau unpredictable perusahaan bersaing dalam mencapai keberhasilannya. Hal ini tentunya dapat dilihat dengan nilai perusahaan itu sendiri. Nilai perusahaan dapat menjadi pedoman atau acuan bagi investor atau stakeholders lainnya di dalam menilai keberlangsungan (going concern) masing-masing perusahaan.

Beberapa

penelitian menyebutkan ada banyak faktor yang dapat mempengaruhi nilai perusahaan. Diantaranya yaitu CSR, yang disebutkan bahwa CSR berpengaruh signifikan terhadap nilai perusahaan (Arafat et al, 2012; Kusumadilaga, 
ISSN 1412-2936

EISSN 2549-7308

2010), namun dalam penelitian yang dilakukan oleh (Agustine, 2012; Maspupah, 2014) menyebutkan bahwa CSR tidak berpengaruh terhadap nilai perusahaan.

Sebagian besar penelitian menunjukkan hasil yang beragam. Menurut (Umro, Madinatul dan Fidiana, 2016) Corporate Social Responsibility (CSR) berpengaruh positif terhadap nilai perusahaan dan profitabilitas tidak berpengaruh terhadap nilai perusahaan. Adapun menurut Agustine (2010) dalam Cecilia (2014), profitabilitas sebagai indikator kinerja

perusahaan berpengaruh positif terhadap nilai perusahaan. Fandini (2013) dan Hermunigsih (2013) juga melakukan penelitian tentang nilai perusahaan tetapi dengan variabel independen yang berbeda, yang menunjukkan bahwa profitabilitas berpengaruh positif terhadap nilai perusahaan. Hasil penelitian ini sejalan dengan penelitian yang dilakukan Kurnia (2015), Pangulu (2014), dan Hemastuti (2014) yang menunjukkan bahwa profitabilitas berpengaruh positif terhadap nilai perusahaan.

Perbedaan penelitian ini dengan penelitian sebelumnya yaitu pada variabel yang digunakan dalam mengukur nilai perusahaan, seperti halnya yang dilakukan oleh (Sudiani, $\mathrm{Ni}$
Kadek Ayu dan $\mathrm{Ni}$ Putu Ayu Darmayanti. 2015), dengan variabel independen yang digunakan yaitu Profitabilitas, Likuiditas, Pertumbuhan, dan Investment Oppurtunity Set Terhadap variabel dependen yaitu Nilai Perusahaan, sedangkan pada penelitian ini variabel independen yang digunakan CSR, Profitabilitas, Likuiditas, Leverage dan Growth, terhadap variabel dependen yaitu nilai perusahaan. Perbedaan lain dengan penelitian sebelumnya adalah objek penelitian. Bank Umum Syariah menjadi objek dalam penelitian ini, hal ini dikarenakan Bank umum syariah merupakan lembaga keuangan yang berasaskan prinsip-prinsip syariah, yang telah dijelaskan di dalam Undang-undang No.10/1998 tentang perbankan Islam dan disempurnakan dalam Undangundang No. 7 tahun 1992, serta diikuti pula dengan Undang-undang No.23/1999 mengenai Bank Indonesia yang memberikan peluang kepada Bank Umum Nasional untuk membuka Unit Usaha Syariah (UUS). Di samping itu, Bank Umum Syariah semakin mengalami perkembangan dan ikut serta dalam memajukan perekonomian dunia, khususnya di Indonesia. Perkembangan Bank Umum syariah juga ditunjukkan dengan naik turunnya 
ISSN 1412-2936

EISSN 2549-7308

saham bank umum syariah dari tahun ke tahun.

Berdasarkan latar belakang yang telah diuraikan di atas, maka rumusan masalah dalam penelitian ini sebagai berikut:

1. Apakah Corporate Social Responsibility berpengaruh terhadap nilai perusahaan?

2. Apakah Profitabilitas berpengaruh terhadap nilai perusahaan?

3. Apakah leverage berpengaruh terhadap nilai perusahaan?

4. Apakah likuiditas berpengaruh terhadap nilai perusahaan?

5. Apakah Growth berpengaruh terhadap nilai perusahaan?

\section{TEORI DAN PENGEMBANGAN HIPOTESIS}

\section{Teori Sinyal (Signaling Theory)}

Teori ini menjelaskan mengapa perusahaan mempunyai dorongan untuk memberikan informasi laporan keuangan pada pihak eksternal. Dorongan perusahaan untuk memberikan informasi karena terdapat asimetri informasi antara perusahaan dan pihak luar karena perusahaan mengetahui lebih banyak mengenai perusahaan dan prospek yang akan datang daripada pihak luar.

Teori Signal menyatakan bahwa perusahaan yang memiliki kualitas baik akan dengan sengaja memberikan signal ke pasar, agar pasar dapat membedakan kualitas perusahaan tersebut dengan perusahaan lainnya (Hartono, 2005) dalam Adnantara (2013). Signal ini dapat berupa promosi atau informasi lainnya, salah satunya adalah informasi tentang Corporate Social Responsibility (CSR), dengan harapan dapat meningkatkan nilai perusahaan (Adnantara, 2013).

Rustiarini (2010) dalam Umro dan Fidiana (2016) teori sinyal membahas mengenai dorongan perusahaan untuk memberikan informasi kepada pihak eksternal maupun pihak internal. Dorongan tersebut disebabkan karena terjadinya asimetri informasi antara pihak manajemen dan pihak eksternal. Untuk mengurangi asimetri informasi maka perusahaan harus mengungkapkan informasi yang dimiliki, baik informasi keuangan maupun non keuangan.

Teori Stakeholder

Secara umum dalam teori stakeholder menunjukkan bahwa perusahaan tidak hanya bertanggung jawab pada kesejahteraan perusahaan saja, melainkan harus memiliki tanggug jawab sosial dengan mempertimbangkan kepentingan semua pihak yang terkena dampak dari tindakan atau kebijakan strategi 
ISSN 1412-2936

EISSN 2549-7308

perusahaan. Kesuksesan suatu (Cecilia, dkk, 2014). Dengan perusahaan sangat tergantung pada menerapkan CSR, diharapkan kemampuannya dalam perusahaan akan memperoleh menyeimbangkan beragam kepentingan dari para stakeholder atau pemangku kepentingan (Lako, 2011).

\section{Corporate Social Responsibility (CSR)}

Corporate Social Responsibility (CSR) dicetuskan sebagai suatu visi akuntabilitas suatu bisnis. Kuncinya adalah terfokus pada proteksi lingkungan dan keselamatan kerja para pekerja, dan pengembangan komunitas dan masyarakat secara umum baik saat ini maupun masa depan (Lilis, 2012). Menurut Djajadiningrat dan Melia, 2004: 35,36 dalam Lilis (2012), Konsep CSR ini mengarahkan bahwa suatu perusahaan tidak akan dapat bertahan lama apabila dia mengisolasikan dan membatasi dirinya dari masyarakat sekitarnya.

Pengungkapan atas kegiatan CSR adalah sinyal yang bagus bagi investor dan stakeholder bahwa perusahaan aktif dalam melakukan kegiatan CSR, serta nilai pasar perusahaan berada dalam posisi yang bagus. Kinerja sosial perusahaan yang bagus membantu perusahaan untuk memperoleh reputasi dari pasar modal dan pasar utang sehingga membuat nilai suatu perusahaan meningkat legitimasi sosial dan memaksimalkan kekuatan keuangannya dalam jangka panjang (Kiroyan, 2006). Hal ini mengindikasikan bahwa perusahaan yang menerapkan CSR mengharapkan akan direspon positif oleh para pelaku pasar.

\section{Profitabilitas}

Profitabilitas adalah kemampuan perusahaan dalam menghasilkan laba (Suharli, 2007). Perusahaan yang dapat mengelola asetnya dengan baik, cenderung menghasilkan kinerja keuangan yang baik pula, yang diwujudkan dengan adanya laba yang tinggi (ROA yang tinggi). Profitabilitas digunakan untuk mengukur sampai sejauh mana keefektifan dari keseluruhan manajemen dalam menciptakan keuntungan bagi perusahaan setelah bunga dan pajak (Sianturi, 2015)dalam (Mariani, 2016).

Profitabilitas yang tinggi mencerminkan kemampuan perusahaan dalam menghasilkan keuntungan yang tinggi bagi pemegang saham. Semakin besar keuntungan yang diperoleh semakin besar pula kemampuan perusahaan untuk membayarkan devidennya, dan hal ini berdampak pada kenaikan nilai perusahaan. 
ISSN 1412-2936

EISSN 2549-7308

Dengan rasio profitabilitas yang tinggi yang dimiliki sebuah perusahaan akan menarik minat investor untuk menanamkan modalnya diperusahaan (Dewi dan Wirajaya, 2013) dalam (I Gusti Ngurah Agung Dwi Pramana, 2016).

\section{Llkuiditas}

Nilai likuiditas yang tinggi mencerminkan kemampuan perusahaan yang tinggi untuk memenuhi kewajiban jangka pendeknya. Perusahaan yang memiliki nilai likuiditas yang baik akan dianggap memiliki kinerja yang baik oleh investor. Menurut Sartono (2010:114) dalam Sudiyani dan Darmayanti (2016) Likuiditas merupakan kemampuan perusahaan untuk memenuhi kewajiban finansial yang berjangka pendek tepat pada waktunya. Ukuran likuiditas perusahaan yang diproksikan dengan current ratio $(\mathrm{CR})$ yang merupakan perbandingan antara aktiva lancar (current asset) dengan hutang lancar (current liabilities). Likuiditas yang tinggi menunjukkan kekuatan perusahaan dari segi kemampuan untuk memenuhi hutang lancar dari harta lancar yang dimiliki sehingga hal ini meningkatkan kepercayaan pihak luar terhadap perusahaan tersebut.

\section{Leverage}

Leverage menggambarkan struktur modal yang dimiliki oleh perusahaan. Leverage dihitung dari total utang dibagi dengan total aset. Perusahaan dengan tingkat leverage yang tinggi menunjukkan bahwa perusahaan lebih banyak bergantung pada utang dalam membiayai aset perusahaan. Utang bagi perusahaan memiliki beban tetap yang berupa beban bunga. Semakin besar utang yang dimiliki perusahaan maka beban bunga yang harus dibayarkan juga semakin tinggi. Perusahaan yang memiliki utang tinggi akan mendapatkan insentif pajak berupa potongan atas bunga pinjaman sehingga perusahaan yang memiliki beban pajak tinggi dapat melakukan penghematan pajak dengan cara menambah utang perusahaan (Suyanto dan Suparmono, 2012).

\section{Growth}

Wahyudi dan Hartini (2006) dalam Ni Kadek Ayu Sudiani dan Ni Putu Ayu Darmayanti menyebutkan bahwa investasi perusahaan dalam aktiva tetap adalah potensi keuntungan bagi perusahaan di masa depan, sehingga growth perusahaan adalah hal positif yang dapat meningkatkan nilai perusahaan. Semakin besar tingkat growth perusahaan maka akan semakin tinggi potensi profitabilitas perusahaan di masa depan sehingga semakin tinggi pula nilai perusahaan. 
ISSN 1412-2936

EISSN 2549-7308

\section{Pengembangan Hipotesis}

Pengaruh Pengungkapan Corporate Sosial Responsibility Terhadap Nilai Perusahaan

Frekuensi dilakukannya

Corporate Social Responsibility oleh perusahaan akan mendongkrak citra perusahaan. Investor lebih berminat pada perusahaan yang memiliki citra baik di masyarakat karena semakin baik citra perusahaan, loyalitas konsumen semakin tinggi sehingga dalam waktu lama penjualan perusahaan akan meningkat dan profitabilitas perusahaan juga akan meningkat (Retno dan Priantinah, 2012) dalam (Mariani,dkk, 2016). Pengungkapan Corporate Social Responsibility perusahaan diharapkan dapat memberikan sinyal yang positif kepada investor, sehingga dapat meningkatkan nilai perusahaan (Cheng dan Christiawan, 2011).Berdasarkan uraian di atas dapat dirumuskan hipotesis sebagai berikut.

$H_{1}$ : Ada pengaruh corporate sosial responsibility (CSR) terhadap nilai perusahaan

\section{Pengaruh ProfitabilitasTerhadap Nilai Perusahaan}

Profitabilitas dalam teori berhubungan positif dengan nilai perusahaan. Semakin tinggi profitabilitas maka nilai perusahaan tinggi dan semakin rendah profitabilitas maka nilai perusahaan rendah. Semakin baik perusahaan membayar return terhadap pemegang saham akan meningkatkan nilai perusahaan. Nilai perusahaan dapat pula dipengaruhi oleh besar kecilnya profitabilitas yang dihasilkan oleh perusahaan. Weston dan Copeland (1992) dalam Prasetyorini (2013) mendefinisikan profitabilitas sejauh mana perusahaan menghasilkan laba dari penjualan dan investasi perusahaan. Apabila profitabilitas perusahaan baik maka para stakeholders yang terdiri dari kreditur, supplier, dan juga investor akan melihat sejauh mana perusahaan dapat menghasilkan laba dari penjualan dan investasi perusahaan. Dengan baiknya kinerja perusahaan akan meningkatkan pula nilai perusahaan.

\section{Pengaruh Likuiditas Terhadap Nilai} Perusahaan

Likuiditas dalam teori berhubungan positif dengan nilai perusahaan. Semakin tinggi likuiditas maka nilai perusahaan tinggi dan semakin rendah likuiditas maka nilai perusahaan rendah. Kemampuan kas yang tinggi akan berdampak terhadap kemampuan kewajiban jangka pendek perusahaan dan berdampak positif terhadap nilai perusahaan (Mahendra, 2012). 
ISSN 1412-2936

EISSN 2549-7308

Likuiditas

menunjukkan kemampuan perusahaan memenuhi kewajiban

untuk jangka pendeknya. Tingkat likuiditas yang tinggi akan menunjukkan bahwa perusahaan berada dalam kondisi yang baik sehingga akan menambah permintaan saham dan tentunya akan menaikkan harga saham (Mahendra, 2011) dalam (Mariani, dkk, 2016). Kemampuan kas yang tinggi akan berdampak pada kemampuan memenuhi kewajiban jangka pendek perusahaan dan berdampak positif pada perusahaan (Mahendra, 2012) dalam (Mariani, dkk, 2016). Semakin tinggi likuiditas perusahaan, semakin banyak dana yang tersedia bagi perusahaan untuk membayar dividen, membiayai operasi dan investasinya, sehingga persepsi investor pada kinerja perusahaan akan meningkat (Nurhayati, 2013) dalam (Mariani, dkk, 2016).

\section{Pengaruh Leverage Terhadap Nilai Perusahaan}

Menurut Jensen (1976) dalam Febrianti (2012), nilai perusahaan dapat meningkat dengan adanya hutang apabila hutang tersebut digunakan bukan untuk investasi yang tidak menguntungkan, melainkan digunakan untuk mengendalikan penggunaan arus kas yang berlebihan oleh pihak manajemen perusahaan.
Leverage dalam

teori berhubungan negatif dengan nilai perusahaan. Semakin tinggi leverage maka nilai perusahaan rendah dan semakin rendah leverage maka nilai perusahaan tinggi. Penggunaan hutang harus hati-hati oleh pihak manajemen, karena semakin besar hutang akan menurunkan nilai perusahaan. Leverage yang parsial dalam hasil penelitian yang dilakukan (Mahendra, dkk, 2012) menemukan memiliki pengaruh negatif tidak signifikan terhadap nilai perusahaan. Berdasarkan uraian di atas dapat dirumuskan hipotesis sebagai berikut.

$\mathrm{H}_{3}$ : Ada pengaruh leverage terhadap nilai perusahaan

Pengaruh Growth Terhadap Nilai Perusahaan

Pertumbuhan perusahaan pada penelitian ini diukur dengan growth (pertumbuhan asset). Pertumbuhan perusahaan adalah selisih total aset yang dimiliki oleh perusahaan pada periode sekarang dengan periode sebelumnya terhadap total aset periode sebelumnya pada perusahaan Bank Umum Syariah di Bank Indonesia periode 2012-2015.

Wahyudi dan Hartini (2006) dalam Ni Kadek Ayu Sudiani dan $\mathrm{Ni}$ Putu Ayu Darmayanti (2016) menyebutkan bahwa investasi 
ISSN 1412-2936

EISSN 2549-7308

perusahaan dalam aktiva tetap adalah potensi keuntungan bagi perusahaan di masa depan, sehingga pertumbuhan perusahaan adalah hal positif yang dapat meningkatkan nilai perusahaan. Berdasarkan uraian di atas dapat dirumuskan hipotesis sebagai berikut.

$\mathrm{H}_{5}$ : Ada pengaruh growth terhadap nilai perusahaan

\section{METODE PENELITIAN}

\section{Jenis dan Desain Penelitian}

Jenis penelitian yang digunakan dalam penelitian ini adalah penelitian kuantitatif. Analisis data dalam penelitian kuantitatif yaitu menggunakan statistik deskriptif.

Variabel dependen penelitian ini adalah nilai perusahaan. Nilai perusahaan merupakan persepsi investor terhadap perusahaan yang sering dikaitkan harga saham. Harga saham yang tinggi membuat nilai perusahaan juga tinggi. Harga saham merupakan harga yang terjadi pada saat saham diperdagangkan di pasar.

Variabel independen yang digunakan dalam penelitian ini yaitu Corporate Social Reponsibility (CSR), profitabilitas, likuiditas, leverage dan growth.

\section{Populasi dan Sampel Penelitian}

\section{Populasi}

Populasi menurut lqbal dalam Aulia (2008:45) adalah totalitas dari semua objek atau individu yang memiliki karakteristik tertentu, jelas, dan lengkap yang akan diteliti (bahan penelitian). Populasi dalam penelitian ini adalah semua peruasahaan Bank Umum Syariah yang terdaftar di Bank Indonesia sebanyak 11 perusahaan.

\section{Sampel}

Sampel adalah bagian dari jumlah karakteristik yang dimiliki oleh populasi tersebut (Sugiyono, 2013:116). Teknik penentuan sampel yang digunakan dalam penelitian ini adalah total sampling dimana pemilihan elemen populasi dilakukan sedemikian rupa sehingga setiap elemen tersebut mempunyai kesempatan yang sama untuk terpilih. Sampel akhir adalah 11 perusahaan Bank Umum Syariah yang terdaftar di Bank Indonesia tahun 20122015. 
ISSN 1412-2936

EISSN 2549-7308

TABEL 2. Daftar total sampling Bank Umum Syariah di Indonesia

\begin{tabular}{|c|l|}
\hline No & \multicolumn{1}{|c|}{ Nama Bank } \\
\hline 1 & PT. Bank Syariah Mandiri \\
\hline 2 & PT. Bank Syariah Muamalat Indonesia \\
\hline 3 & PT. Bank Syariah BNI \\
\hline 4 & PT. Bank Syariah BRI \\
\hline 5 & PT. Bank Syariah Mega Indonesia \\
\hline 6 & PT. Bank Jabar Banten Syariah \\
\hline 7 & PT. Bank Panin Syariah \\
\hline 8 & PT. Bank Syariah Bukopin \\
\hline 9 & PT. Bank Victoria Syariah \\
\hline 10 & PT. BCA Syariah \\
\hline 11 & PT. Maybank Indonesia Syariah \\
\hline
\end{tabular}

Teknik Analisis Data dan Uji Statistik Statistik Deskriptif

Statistik deskriptif digunakan untuk menjelaskan deskripsi data dari seluruh variabel yang akan dimasukkan dalam model penelitian yang dilihat dari nilai minimum, nilai maksimum, nilai rata-rata dan standar deviasi.

\section{Uji Asumsi Klasik}

Uji asumsi klasik dilakukan untuk mengetahui data yang layak untuk dianalisis. Pengujian data dalam penelitian ini yaitu:Uji Normalitas, Uji Multikolinearitas, Uji Autokolerasi, dan Uji Heterokedastisitas.

\section{Teknik Analisis}

\section{Uji Regresi}

Berdasarkan pada hipotesis yang diajukan, metode analisis yang digunakan untuk membuktikan hipotesa adalah metode statistik regresi linier berganda. Analisis regresi bertujuan untuk mencari adanya hubungan antara variabel dependen dengan satu atau lebih variabel independen. Persamaan yang digunakan untuk menguji hipotesa adalah:

$Y=a+b_{1} X_{1}+b_{2} X_{2}+b_{3} X_{3}+b_{4} X_{4}+e$

Keterangan :

Y : Nilai perusahaan

a $\quad$ : Intersep (atau nilai $Y$ pada saat $\mathrm{X}=0$ )

b : Koefisien regresi

$\mathrm{X}_{1} \quad$ : Corporate Social Responsibility (CSR)

$\mathrm{X}_{2}$ : Profitabilitas

$\mathrm{X}_{3} \quad$ : Leverage

$\mathrm{X}_{4} \quad$ : Likuiditas

e : Galat / standart error

Untuk kepentingan analisis data tersebut, dipergunakan program komputer SPSS 23. Pengujian hipotesis dilakukan dengan uji t, namun sebelum meregresi data, dilakukan uji asumsi klasik regresi.

\section{Uji Hipotesis}

Penelitian ini menggunakan regresi berganda. Bentuk persamaan dalam penelitian ini adalah:

$\mathrm{Y}=\mathrm{a}+\mathrm{b}_{1}+\mathrm{b}_{2} \mathrm{X} 2+\mathrm{b}_{3} \mathrm{X} 3+\mathrm{b}_{4} \mathrm{D} 1+\mathrm{e}$

Keterangan:

$Y$ : Nilai Perusahaan

X1 : Corporate Social Responsibility Disclosure (CSRD) 
X2 : Profitabilitas (Return on Total Leverage/ROA)

X3 : Leverage

X4 : Likuiditas (Current Ratio/CR)

$\mathrm{b}_{1}, \ldots, \mathrm{b}_{5}:$ Koefisien regresi

e : Error

Penelitian ini menggunakan analisis regresi linier berganda karena untuk mengetahui pengaruh variabel independen (CSR, profitabilitas, leverage, dan likuiditas) terhadap variabel dependen (nilai perusahaan). Alasan lain peneliti menggunakan analisis regresi linier berganda karena variabel independennya lebih dari satu.

\section{PEMBAHASAN}

Metode analisis data yang digunakan dalam penelitian ini menggunakan path analysis dengan SPSS 23.

\section{Uji Normalitas}

Uji normalitas dilakukan untuk menguji apakah dalam model regresi variabel pengganggu atau residual memiliki distribusi normal. Uji normalitas data menggunakan analisis statistik non-parametrik uji Kolmogorov-Smirnov. Dalam uji ini variabel yang mempunyai asymp. Sig < 0,05 maka diartikan bahwa variabel-variabel tersebut memiliki distribusi tidak normal (Ghozali, 2006:110). Hasil uji normalitas berikut ini. 
ISSN 1412-2936

EISSN 2549-7308

Tabel 3. Hasil Uji multikolinearitas

\begin{tabular}{|c|l|c|}
\hline No & Variabel Independen & VIF \\
\hline 1 & CSR & 1.181 \\
2 & Profitabilitas & 1.072 \\
3 & Likuiditas & 1.108 \\
4 & Leverage & 1.152 \\
5 & Growth & 1.063 \\
\hline
\end{tabular}

\section{Uji Autokolerasi}

Uji autokolerasi bertujuan menguji apakah dalam model regresi linear ada korelasi antara kesalahan pengganggu pada periode $t$ dengan kesalahan pengganggu pada periode $\mathrm{t}-1$ (sebelumnya). Deteksi adanya autokorelasi dapat dilihat dari angka DW (Durbin-Watson). Angka D-W dibawah 2 berarti ada autokorelasi positif. Berikut hasil pengujian autokorelasi.

Tabel 4. Hasil Uji Autokorelasi

\begin{tabular}{|c|c|c|c|c|c|}
\hline \multicolumn{6}{|c|}{ Model Summary } \\
\hline Model & $\mathrm{R}$ & R Square & $\begin{array}{c}\text { Adjusted R } \\
\text { Square }\end{array}$ & $\begin{array}{l}\text { Std. Error of } \\
\text { the Estimate }\end{array}$ & $\begin{array}{l}\text { Durbin- } \\
\text { Watson }\end{array}$ \\
\hline 1 & $.845^{\mathrm{a}}$ & .714 & .676 & 5.11482 & 1.704 \\
\hline
\end{tabular}

\section{Uji Heterokedastisitas}

Uji heteroskedastisitas bertujuan menguji apakah dalam model regresi terjadi ketidaksamaan variance dari residual satu pengamatan ke pengamatan yang lain. Pengujian ini juga bertujuan untuk menguji apakah dalam model regresi terjadi ketidaksamaan deviasi standar nilai variabel dependen pada setiap variabel independen. Model regresi yang baik adalah yang homokedastisitas atau tidak terjadi heteroskedastisitas. Penelitian ini menggunakan Grafik Plot, dasar analisis:

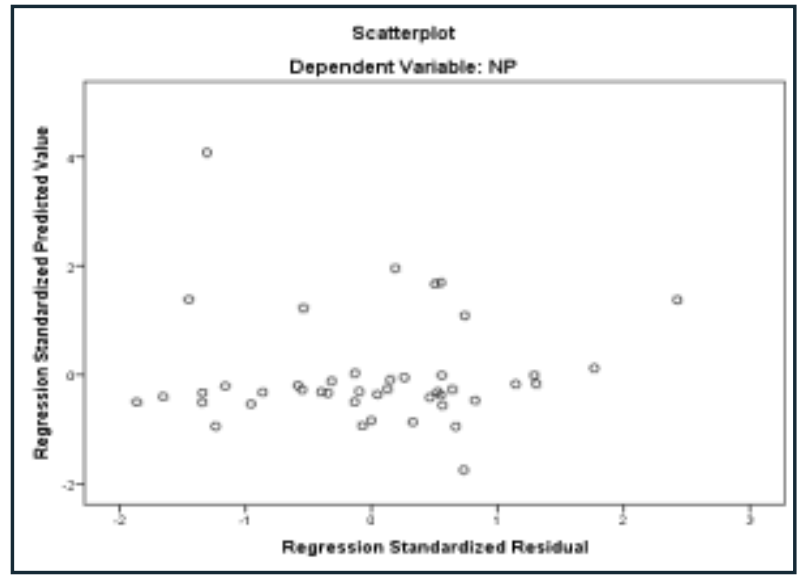

Gambar 2. Hasil Uji Heterokedastisitas

Berdasarkan gambar 2 grafik scatterplots terlihat bahwa titik-titik menyebar secara acak serta tersebar baik di atas maupun di bawah angka 0 pada sumbu y dan titik membentuk pola tertentu. Dengan demikian dapat disimpulkan bahwa tidak terjadi heterogenitas pada model persamaan regresi yang digunakan.

Tabel 4. Hasil Uji Regresi

\begin{tabular}{|c|c|c|c|c|c|}
\hline \multicolumn{6}{|c|}{ Coefficients $^{a}$} \\
\hline & & \multicolumn{2}{|c|}{$\begin{array}{c}\text { Unstandardized } \\
\text { Coefficients }\end{array}$} & \multirow[b]{2}{*}{$\mathrm{T}$} & \multirow[b]{2}{*}{ Sig. } \\
\hline \multicolumn{2}{|c|}{ Model } & B & Std. Error & & \\
\hline \multirow[t]{6}{*}{1} & (Constant) & 30.544 & 2.448 & 12.476 & .000 \\
\hline & CSR & $1.831 \mathrm{E}-9$ & .000 & 6.925 & .000 \\
\hline & Profitabilitas & 3.563 & 18.263 & .195 & .846 \\
\hline & Likuiditas & .039 & .018 & 2.218 & .033 \\
\hline & Leverage & -2.437 & 1.038 & -2.347 & .024 \\
\hline & Growth & -2.054 & 1.728 & -1.189 & .242 \\
\hline \multicolumn{6}{|c|}{ a. Dependent Variable: NP } \\
\hline
\end{tabular}


ISSN 1412-2936

EISSN 2549-7308

Berdasarkan persamaan tersebut

nilai 30.544

merupakan

intersep/konstanta, nilai tersebut merupakan nilai dari variabel nilai perusahaan apabila CSR, profitabilitas, likuiditas, leverage dan growth ditetapkan sama dengan nol, maka nilai perusahaan diproksikan dengan return saham sebesar 30.544 .

Tabel tersebut juga menunjukkan signifikansi antar variabel, yaitu CSR, likuiditas dan leverage memiliki signifikansi sebesar $0.000 \quad 0.033$ dan 0.024 yang artinya CSR, likuiditas dan leverage berpengaruh positif terhadap nilai perusahaan, sedangkan profitabilitas dan growth berpengaruh negatif terhadap nilai perusahaan dengan signifikansi sebesar 0.846 dan 0.242 .

\section{SIMPULAN}

Hasil penelitian menunjukkan bahwa CSR, likuiditas, dan leverage memberikan kontribusi dalam meningkatkan nilai perusahaan. Hasil penelitian ini juga menunjukkan profitabilitas dan growth tidak memberikan kontribusi dalam meningkatkan nilai perusahaan.

\section{IMPLIKASI}

Perusahaan yang dijadikan sampel dalam penelitian ini tidak dapat memanfaatkan modal yang dimiliki untuk meningkatkan profit dengan baik sehingga ada perusahaan yang mengalami kerugian.

\section{SARAN}

Bagi perusahaan khususnya Bank Umum Syariah yang memiliki tingkat profitabilitas yang rendah, sebaiknya lebih baik dalam pengelolaan asetnya dan kebijakan hutangnya. Hal ini dikarenakan ROE adalah fungsi dari profit margin, assets turnover dan equity multiplier. Adapun langkah-langkah yang dilakukan untuk meningkatkan profitabilitas yaitu mengurangi harga pokok penjualan atau beban operasi perusahaan, meningkatkan penjualan tanpa adanya peningkatan beban atau biaya secara proposional, dan meningkatkan penggunaan utang relative terhadap ekuitas sampai titik yang tidak membahayakan keuangan perusahaan.

Bagi perusahaan khususnya Bank Umum Syariah yang memiliki tingkat growth yang rendah, sebaiknya memilih strategi pertumbuhan yang tepat, fokus pada penetrasi pasar, perkuat pada segmen mikro, dan inovasi produk.

\section{DAFTAR PUSTAKA}

Adnantara, Komang Fridagustina. 2013. Pengaruh Struktur Kepemilikan Saham dan Corporate Social Responsibility. Jurnal Buletin Studi 
ISSN 1412-2936

EISSN 2549-7308

Ekonomi, Vol. 18, 108 No. 2, Agustus 2013

Aijia, Shochrul R. 2011. Cara Cerdas Menguasai E-Views. Jakarta: Salemba Empat.

Cecilia, dkk. 2014. Analisis Pengaruh Corporate Social Responsibility, Profitabilitas dan Ukuran Perusahaan Terhadap Nilai Perusahaan pada Perusahaan Perkebunan yang Go Public di Indonesia, Malaysia, dan Singapura.SNA 18. Universitas Sumatera Utara.

Cheng, Ming-Chang \& Zuwei-Ching Tzeng. 2011. The Effect of Leverage on Firm Value and How The Firm Financial Quality Influence on This Effect. World Journal of Management Vol. 3. No. 2. September 2011 Pp. 30-53

Febrianti, Meiriska. 2012. Faktor-faktor yang Mempengaruhi Nilai Perusahaan Pada Industri Pertambangan di Bursa Efek Indonesia. Jurnal bisnis dan akuntansi, Vol. 14, No. 2, Agustus 2012

Ghozali, Imam. 2006. Aplikasi Analisis Multivariate dengan Program SPSS. Edisi kedua. Semarang : Badan Penerbit Universitas Diponegoro

Hardiningsih, Pancawati. 2012. Determinan Nilai Perusahaan. JAI Vol.5, No.2, Juli 2009 : 231-250

Herawati, Titin. 2012. Pengaruh Kebijakan Deviden, Kebijakan Hutang, dan Profitabilitas Terhadap Nilai Perusahaan

Hermuningsih, Sri. 2013. Pengaruh Profitabilitas, Growth Opportunity, Struktur Modal Terhadap Nilai Perusahaan Pada Perusahaan Publik di Indonesia. Buletin Ekonomi Moneter dan Perbankan, Oktober 2013.

Ikhlas Arfan, dan Herkulanus Bambang Suprasto. 2008. Teori Akuntansi dan Riset Multiparadigma. Yogyakarta: Graha ilmu.
Ekawati, Lilis, et al. 2012. Pengaruh Profitabilitas, Likuiditas, Growth, dan Media Exposure Terhadap Pengungkapan Tanggungjawab Sosial Perusahaan.

Kusumayanti \& Astika. 2016 Corporate Social Responsibility sebagai Pemediasi Pengaruh Ukuran Perusahaan, Profitabilitas, dan Leverage Pada Nilai Perusahaan. EJurnal Akuntansi Universitas Udayana. Vol.15.1 April (2016): 549-583.

Lako, Andreas 2011. Dekonstruksi CSR \& Reformasi Paradigma Bisnis \& Akuntansi. Jakarta: Penerbit Erlangga

Mahendra, Alfredo, et al. 2012. Pengaruh Kinerja Keuangan Terhadap Nilai Pada Perusahaan Manufaktur di Bursa Efek Indonesia. Jurnal Manajemen, Strategi Bisnis, dan Kewirausahaan Vol. 6, 137, No. 2 Agustus 2012

Mardiyati, et al. 2012. Pengaruh Kebijakan Deviden, Kebijakan Hutang dan Profitabilitas Terhadap Nilai Perusahaan Manufaktur yang Terdaftar di Bursa Efek Indonesia (BEI) Periode 2005-2010. Jurnal Riset Manajemen Sains Indonesia (JRMSI) |Vol. 3, No. 1, 2012

Mariani, Eny Wayan, et al. 2016. Kemampuan Good Corporate Governance dan CSR Memoderasi Pengaruh Likuiditas, Solvabilitas, dan Profitabilitas Pada Nilai Perusahaan. E-Jurnal Ekonomi dan Bisnis Universitas Udayana 5.9 (2016): 2801-2836. ISSN : 23373067

Mokoagow, Sri Windarti \& Misbach Fuady. 2015. Faktor-Faktor yang Mempengaruhi Profitabilitas Bank Umum Syariah di Indonesia. Vol. 6, No. 1, Juli 2015 Halaman : $33-62$

Ogolmagai, Natalia. 2013. Leverage Pengaruhnya Terhadap Nilai Perusahaan Pada Industri Manufaktur yang Go Public di Indonesia. Jurnal EMBA 82 : Vol.1 
ISSN 1412-2936

EISSN 2549-7308

No.3 Juni 2013, Hal. 81-89. ISSN 2303-1174

Parminto, Ardi, et al. 2016. The Effect of Capital Structure, Firm Growth and Dividend Policy on Profitability and Firm Value of the Oil Palm Plantation Companies in Indonesia. European Journal of Business and Management. ISSN 2222-1905 (Paper) ISSN 2222-2839 (Online)Vol.8, No.33, 2016

Pradipta, Dyah Hayu \& Supriyadi (2012) Pengaruh Corporate Social Responsibility (CSR), Profitabilitas, Leverage, dan Komisaris Independen Terhadap Praktik Penghindaran Pajak

Pramana, I Gusti Ngurah Agung \& I Ketut Mustanda. 2016. Pengaruh Profitabilitas dan Size Terhadap Nilai Perusahaan dengan CSR sebagai Variabel Pemoderasi. E-Jurnal Manajemen Unud, Vol. 5, No.1, 2016: 561 - 594 ISSN: 2302-8912

Prasetyorini, Bhekti Fitri. 2013. Perngaruh Ukuran Perusahaan, Leverage, Price Earning Ratio, dan Profitabilitas Terhadap Nilai Perusahaan. Jurnal IImu manajemen, Vol. 1. No. 1

Sholichah, Wulan Aminatus \& Andayani. 2015. Pengaruh Struktur Kepemilikan, Ukuran Perusahaan dan Leverage Terhadap Nilai Perusahaan. Jurnal IImu \& Riset Akuntansi, Vol. 4. No. 10

William Sucuahi1 \& Jay Mark Cambarihan1. 2016. Influence of Profitability to the Firm Value of Diversified Companies in the Philippines. Accounting and Finance Research Vol. 5, No. 2; 2016

Sudiani, Ni Kadek Ayu dan Ni Putu Ayu Darmayanti. 2016. Pengaruh Profitabilitas, Likuiditas, Pertumbuhan, dan Investment Oppurtunity Set Terhadap Nilai Perusahaan. E-Jurnal Manajemen Unud, Vol. 5, No.7, 2016: 4545-4547
Sugiyono. 2010. Metode Penelitian Kuantitatif, Kualitatif dan R\&D. Bandung: CV. Alfabeta

Suharli, M. 2007. Pengaruh Profitability dan Investment Opportunity Set Terhadap Kebijakan Dividen dengan Likuiditas Sebagai Variabel Penguat. Jurnal Akuntansi dan Keuangan, 9 (1): 9-17

Sujoko \& Ugy Subiantoro. 2007. Pengaruh Struktur Kepemilikan Saham, Leverage, Faktor Intern Dan Faktor Ekstern Terhadap Nilai Perusahaan (Studi empirik pada perusahaan manufaktur dan non manufaktur di Bursa Efek Jakarta). Jurnal Manajemen dan Kewirausahaan, Vol. 9, No. 1, Maret $2007: 41-48$

Supranto, J. 2008. Statistik Teori dan Aplikasi. Edisi ketujuh. Penerbit: Erlangga

Syukron, Ali. 2015. CSR dalam Perspektif Islam dan Perbankan Syariah.Economic. Jurnal Ekonomi dan Hukum Islam, Vol.5.No.1

Tjia, Olivia \& Lulu Setiawati. 2012. Effect of CSR Disclosure to Value of the Firm: Study for Banking Industry in Indonesia World Journal of Social Sciences. Vol. 2. No. 6. September 2012 Issue.

Toin, Dyah Rosna Yustani. 2014. Analisis Kinerja Perbankan (Studi Komparasi Antara Perbankan Syariah Dan Konvensional). Jurnal Siasat Bisnis Vol. 18 No. 2, Juli 2014 Umro, Madinatul \& Fidiana, 2016. Pengaruh Corporate Social Responsibity dan Profitabilitas Terhadap Nilai Perusahaan. Vol. 5.No.1 